\title{
Harvard Business School Press
}

\section{THE ESSENTIAL ALFRED CHANDLER}

Essays Toward a Historical Theory of Big Business

edited and with an Introduction by

Thomas K. McCraw

NOW IN PAPERBACK

In four decades of scholarship, Alfred Chandler has established himself as the acknowledged dean of business historians. Included are sixteen essays and a capsule intellectual biography of Chandler, as well as an introduction to each essay.

"A collection ... that enables us to see where [Chandler's] vision came from and why it has

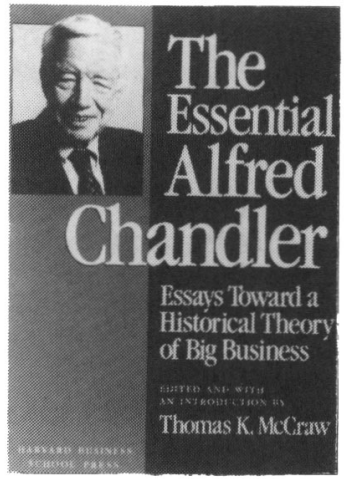
had such an impact, not only on the study of U.S. business history but on scholars in many countries and in several disciplines as well." - Mary Yeager, Journal of Economic History

"This whole presentation, based on a wealth of historical cases, is an outstanding achievement."

-Maurice Lévy-Leboyer, Business History Review

544 pages ISBN 0-87584-306-9 \$19.95 paper

\section{LABORS OF A MODERN HERCULES}

\section{The Evolution of a Chemical Company}

Davis Dyer and David B. Sicilia

Traces the evolution of Hercules Incorporated from its beginnings as a small maker of explosives to its current status as a multimillion dollar, multinational chemical company. The Hercules story provides valuable insights into the growth of U.S. companies in general during the 20th century, and the dynamics of the chemical industry in particular.

512 pages ISBN 0-85784-227-5 \$50.00 hardcover

To order, please call 1-800-545-7685.

Exam copies: 1-617-495-6032. Please write for a complete catalog.

HARVARD BUSINESS SCHOOL PRESS, BOSTON, MA 02163 


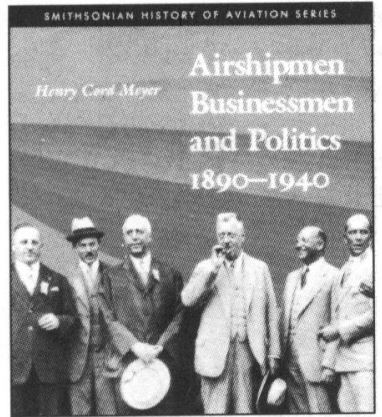

\section{AIRSHIPMEN, BUSINESSMEN, AND POLITICS, 1890-1940}

Henry Cord Meyer

Demonstrating how business, politics, and personal ambition seize new technology, this book introduces the politicians and airship company executives who exploited public enthusiasm over the new rigid airships, or dirigibles, the first aircraft capable of crossing the oceans with significant numbers of people and cargo. Count Ferdinand von Zeppelin, Johann Schütte, Dr. Hugo Eckener, and others profiled are ultimately seen as caught up positively, or enmeshed tragically, in the larger political forces of their time. 95 b\&w illus. $276 \mathrm{pp}$.

Cloth: 1-56098-031-1 \$45.00

\section{HOWARD HUGHES}

\section{AND TWA}

Robert W. Rummel

Written by a former TWA executive and close associate of Hughes, this book provides an insider's view of Hughes's driven, often bizarre personal and business practices during a turbulent time in the development of transport aviation.

59 b\&willus. 442 pp. Cloth: 1-56098-017-6\$29.95
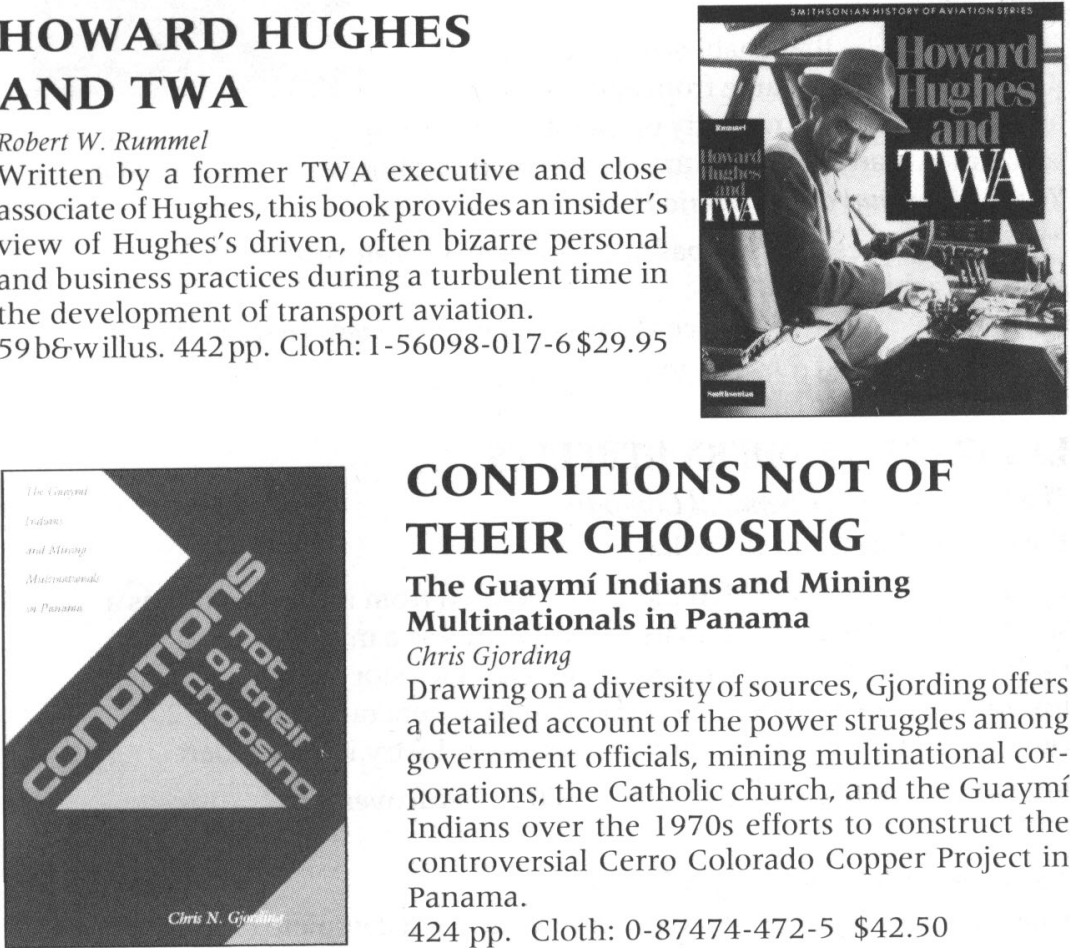

\section{CONDITIONS NOT OF THEIR CHOOSING}

The Guaymí Indians and Mining Multinationals in Panama

Chris Gjording

Drawing on a diversity of sources, Gjording offers a detailed account of the power struggles among government officials, mining multinational corporations, the Catholic church, and the Guaymí Indians over the 1970s efforts to construct the controversial Cerro Colorado Copper Project in Panama. 424 pp. Cloth: 0-87474-472-5 \$42.50

\section{SMITHSONIAN INSTITUTION PRESS}

Dept. 900 . Blue Ridge Summit, PA 17294-0900

800/782-4612 . 717/794-2148 


\section{anagers, entrepreneurs, industrialists . . .}

\section{Taylorism Transformed}

Scientific Management Theory since 1945 by Stephen P. Waring

Examines the evolution of modern business management theories and techniques. Stephen Waring maintains that despite differences, Frederick Taylor's successors have perpetuated his vision of bureaucratic firms governed by scientific managers.

302 pp., $\$ 34.95$

\section{Profits in the Wilderness}

Entrepreneurship and the Founding of New England Towns in the Seventeenth Century by John Frederick Martin

John Frederick Martin demonstrates that the entrepreneurial spirit was as important as the Puritan religious spirit in the founding of New England towns, defying received notions of New England's communal, democratic values.

approx. 340 pp., $\$ 34.95$ cloth, $\$ 12.95$ paper

Published for the Institute of Early American History and Culture, Williamsburg, Virginia

\section{James Bowron}

The Autobiography of a New South Industrialist by Robert J. Norrell

"An extremely valuable source on the business history of the New South." — Lacy K. Ford, Jr.

The previously unpublished autobiography of James Bowron, a prominent Alabama iron and steel industrialist, affords a vivid picture of turn-of-thecentury labor relations and business practices.

approx. 300 pp., $\$ 39.95$ 


\section{THE}

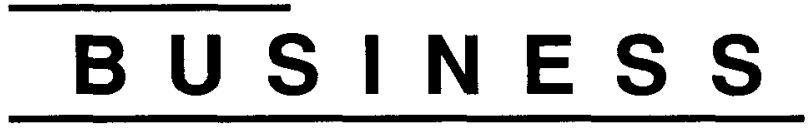

\section{O F}

\section{NATIO N}

\section{$B \cup|L D| N G$}

\section{Close TIES}

Railways, Government, and the Board of Railway Commissioners, 1851-1933

\section{Ken Cruikshank}

Focusing on the historic controversies surrounding freight rates, Close Ties explores the ways in which Canadians tried to regulate the nation's first big business, the railways. Ken Cruikshank challenges earlier interpretations, concluding that the history of railway regulation in Canada is not a story of powerful business corporations using governments to subvert the people's interests, nor a tale of righteous people overcoming robber barons. Instead, he presents a more complex and engaging account of how governments tried to accommodate the equally selfish demands of divergent and conflicting interests in a competitive economy.

December 288 pp $\quad 6 \times 9$ Cloth ISBN 0.7735-0854-6 $\$ 44.95$

\section{POWER AT COST}

\section{Ontario Hydro and Rural Electrification, 1911-1958}

\section{Keith R. Fleming}

Almost from the moment of its creation in 1906, Ontario Hydro has been criticized for pursuing its own interests at the expense of the public it was established to serve. In Power at Cost, Keith Fleming demonstrates that while Hydro exercised tremendous influence over its political masters in the Ontario government, it nevertheless cooperated with the public and a succession of provincial governments in formulating rural electrification policies. Power at Cost will become the standard reference on the subject of rural electrification in Ontario.

December $320 \mathrm{pp} \quad 6 \times 9 \quad 16 \mathrm{b \& w}$ illustrations Cloth ISBN 0-7735-0868-6 $\$ 39.95$

$\begin{array}{lll}\text { Q1FGill } & \text { McGill-Queen's } & \text { 3430 McTavish Street, Montreal } \\ \text { Queenis } & \text { University Press } & \text { Quebec H3A 1X9 Canada }\end{array}$




\section{THE ECONOMIC STRUCTURE OF CORPORATE LAW}

Frank H. Easterbrook and

Daniel R. Fiscbel

"The first comprehensive economic analysis of corporate law... The field will be well served by Easterbrook and Fischel's brilliant effort. This compelling work must inform every future legal debate about either large publicly held corporations or small closely held ones. The authors have demonstrated the power and the essentiality of economic analysis to understanding diverse topics such as limited liability, hostile takeovers, corporate altruism, and a range of other issues." - Henry G. Manne, Dean,

School of Law, George Mason University $\$ 39.95$ cloth

\section{FAVORITES OF FORTUNE}

Technology, Growth, and Economic Development since the Industrial Revolution Edited by Patrice Higonnet, David S. Landes, Henry Rosovsky

In Favorites of Fortune a galaxy of distinguished international economists and historians pit economic history against the shaky assumptions of the classical economic theory of natural growth. Their explanations consider the factors of technology, entrepreneurialism, and paths to economic growth, but each reflects an ideological wave of explanation that has marked the last 200 years. No economic historian will be able to ignore these writings.

$\$ 45.00$ cloth

\section{ENTERPRISE AND AMERICAN LAW, \\ 1836-1937 \\ Herbert Hovenkamp}

In this integration of law and economic ideas, Herbert Hovenkamp charts the cvolution of the legal framework that regulated American business enterprise from the time of Andrew Jackson through the first New Deal. He reveals the interdependent relationship between economic theory and law that existed in these decades of headlong growth and examines how this relationship shaped both the modern business corporation and substantive due process.

$\$ 39.95$ cloth

\section{CAPITAL AND LABOR IN AMERICAN COPPER,}

\section{5-1990}

A Study of the Linkages between

Product and Labor Markets

George H. Hildebrand and Garth L. Mangum

This book is the first comprehensive study of the American copper industry to include labor markets, unionism, and labor relations as an integral part of its focus. It also undertakes a careful examination of the influences exerted by geography and geology in the shaping of the industry. Wertbeim Publications in Industrial Relations, 12 $\$ 25.00$ cloth

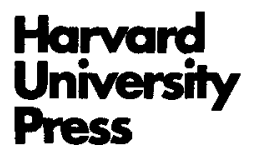

79 Garden Street, Cambridge, MA 02138 (6) 17) 495-2480 


\title{
GUIDELINES FOR CONTRIBUTORS
}

\author{
General Information
}

Manuscripts are considered for publication on the understanding that they are not concurrently under consideration elsewhere and that the material-in substance as well as form-has not been previously published.

Three copies of the manuscript should be submitted.

Authors should identify themselves only on a separate title page that provides name, mailing address, and telephone number. Authors must also remember not to identify themselves in the body of the manuscript; specifically, references to their own work in the text should be in the third person, and citations should be written without possessive pronouns-not "See my. . . ."

Each article should be accompanied by a précis of $75-100$ words outlining the main point(s) of the paper and placing the article in context. Subheads should be used to divide the manuscript into three or four sections (or more, depending on length).

We do not have an upper or lower page limit, but articles usually run between 25 and 60 typescript pages, including notes and other material.

Articles must contain notes in the humanities style, not references as in the social sciences.

We are always eager to publish illustrations, but authors should not include originals of illustrative materials at the time of submission; photocopies of such material may be included.

Authors of accepted manuscripts will receive two copies of the issue in which the article appears and twenty-five free offprints.

\section{Manuscript Prepamtion}

ALL material-including extracted quotations and notes-must be double-spaced. Legible photocopies or word-processed originals may be submitted. Use of dot-matrix printers is discouraged.

Notes should be numbered consecutively and citations should be placed at the end of the text . Do not place footnotes at the bottom of the page (see word-processing instructions).

Each table or figure should occupy a separate page and should be numbered (in arabic numerals) and grouped together between the text and the notes. The position of these items should be indicated in the text (as, "see Table 3"'), but they should not be mingled with the text and no extra space should be left for them there. Each table and figure must be accompanied by a complete source.

We use the 13th edition of The Chicago Manual of Style (1982) and spell and hyphenate words according to Webster's Ninth New Collegiate Dictionary.

The journal encourages authors to use gender-neutral prose in all cases where it is not anachronistic to do so; male nouns and pronouns should not be used to refer to people of both sexes.

We use the day-month-year form for dates, as 11 February 1990.

Double quotation marks should be used for journal titles and direct quotation; single quotation marks are used for quoted material inside quotations.

\section{Sample Citation Forms:}

Book: Alfred D. Chandler, Jr., The Visible Hand: The Managerial Revolution in American Business (Cambridge, Mass., 1977), 321-22.

Journal: Charles Cheape, "Not Politicians but Sound Businessmen: Norton Company and the Third Reich," Business History Reviow 62 (Autumn 1988): 444-66.

Note that we do not include the publisher in book citations. We do not use loc. cit., op. cit., or idem., but ibid. (not italicized) may be used.

\section{Wont-Processing Guidelines}

The journal can accept disks of all standard sizes and densities, but they must be formatted in MS-DOS; we cannot use Apple or MacIntosh software. WordPerfect is directly compatible, but we may be able to accept your document if it can be converted into an ASCII file.

Potential contributors should submit hard copy, not diskettes, initially, but it will save considerable work for all parties in the event of acceptance if authors working on PCs follow a few rules from the beginning:

In general, use as few formatting commands as possible.

Do not justify or half-justify the right-hand margin.

Do not hyphenate words at the end of lines.

Do not use hard returns except for new paragraphs or required page ends except as absolutely necessary (for example, to break between text and notes).

Do not use special fonts; underline material that is to be set in italics.

Most important, do not use the word processor's automatic footnote functions: do not embed notes in the text. Notes should be keyed in at the end of the text (after any tables) or as a separate file. 

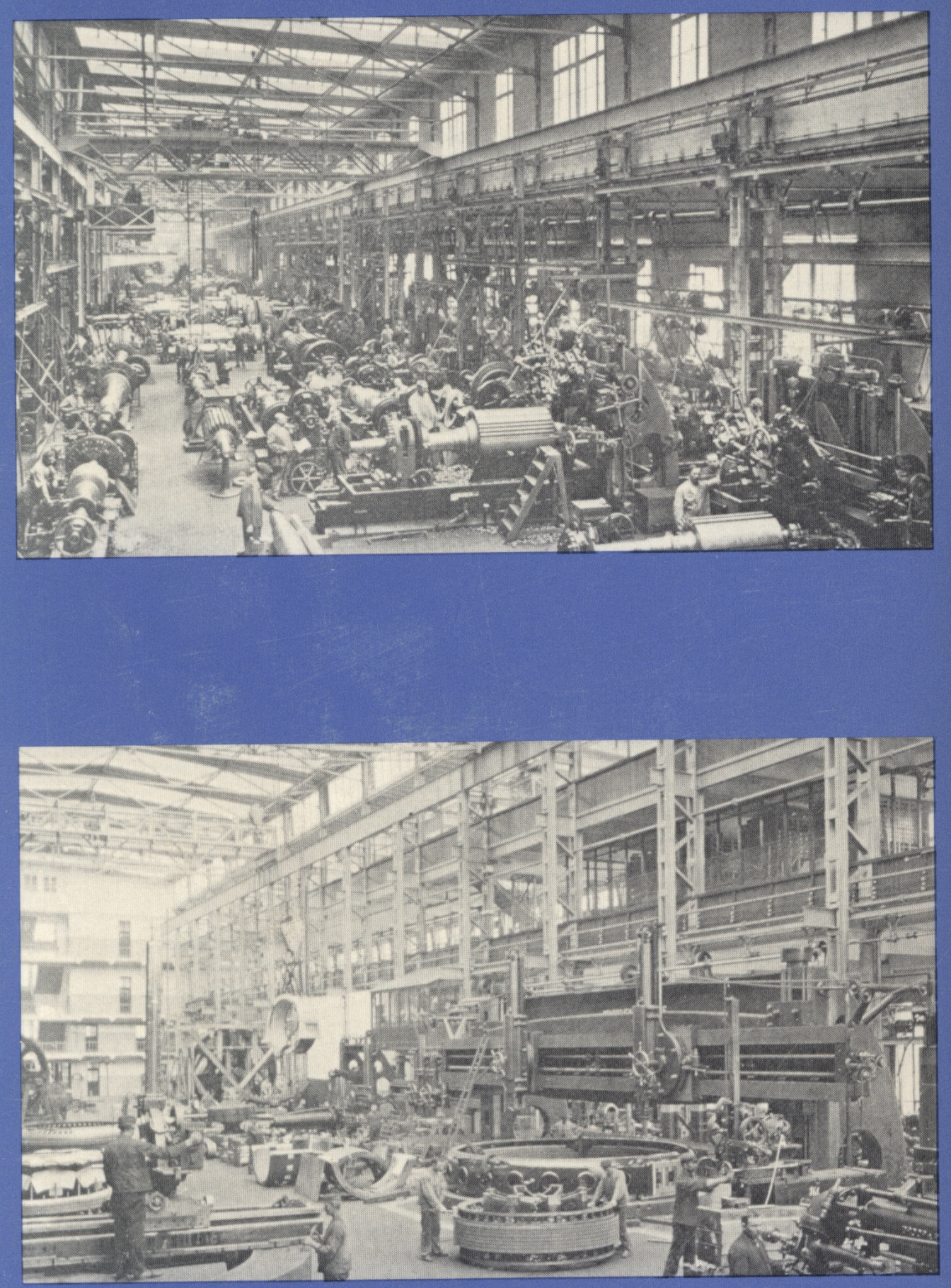